\title{
The Status of the Withdrawal Agreement in UK Law
}

\author{
CATHERINE BARNARD
}

\subsection{Introduction}

Taking the long view, the Withdrawal Agreement (WA) is likely to be remembered for two matters: the position it takes on the protection of citizens' rights (provisions which have the potential, as we shall see, to last for well over a century) and the provisions of the Protocol which could last indefinitely - or perhaps no longer than four years, depending on the outcome of consent votes in the Northern Ireland Assembly. ${ }^{1}$ This chapter looks primarily at the effect of the WA in the UK as a whole. ${ }^{2}$ It will focus on the implementation of the WA in UK law, the enforcement of rights under the Protocol, as they relate to the UK, and the position of EU citizens and their rights.

\subsection{Implementation of the WA into UK Law}

The WA, an international treaty, provided for the exit of the UK from the EU. Under the UK's dualist approach, Parliament was required to legislate in order to give the WA legal effect in the UK. This was accomplished by the European Union (Withdrawal Agreement) Act 2020 (EUWAA 2020) which, in part, amended the European Union (Withdrawal) Act 2018 (EUWA 2018). The WA took effect in UK law from exit day (31 January 2020, at $11.00 \mathrm{pm}$ ). ${ }^{3}$ The Trade and Cooperation Agreement (TCA), which regulates future relations between the EU and the UK and applies in tandem with the provisions of the WA, came into effect in the UK

${ }^{1}$ See further Chapter 10.

${ }^{2}$ Chapter 10 considers the operation of the Protocol in Northern Ireland law, and Chapter 11 considers the legal status of the Protocol in Ireland.

3 As a result of s 5 EUWAA 2020. Exit day (as defined in EUWA 2018, s 20(1)-(5)): see SI 2020/75, reg 4(c). 
via the European Union (Future Relations) Act 2020 (EUFRA) at the end of December 2020.

What was to be done about the significant mass of EU law that applied in the UK prior to the UK's exit? Although the UK left the EU on 31 January 2020, under the terms of the WA, the UK then entered into a period of transition (or, in British terminology, implementation), which lasted from 1 February 2020 to $11 \mathrm{pm}$ on 31 December 2020, Implementation Period Completion Day (IPCD). During this transition/implementation period, most of EU law continued to apply in the UK, as EU law. ${ }^{4}$ EUWA 2018 provided that when the UK finally left the EU, all EU legislation then applying was to be 'on-shored' into UK law, becoming 'retained EU law' and giving powers to ministers to amend that legislation where retained EU law no longer operates effectively. Section 5(2) EUWA 2018 provides for the continuation of the supremacy of this EU retained law over conflicting pre-Brexit UK law.

The 2018 Act, as amended, gives effect to the whole of the WA (including the Protocol) in UK law and also gives ministers specific powers to implement matters affecting the Protocol. The principal conduit pipe for the incorporation of the UK's obligations under the WA is section 7A EUWA 2018 ('General implementation of remainder of withdrawal agreement'), introduced as a result of section 5 of EUWAA 2020. The key parts of section 7A provide:

(1) Subsection (2) applies to -

(a) all such rights, powers, liabilities, obligations and restrictions from time to time created or arising by or under the withdrawal agreement, and

(b) all such remedies and procedures from time to time provided for by or under the withdrawal agreement, as in accordance with the withdrawal agreement are without further enactment to be given legal effect or used in the United Kingdom.

(2) The rights, powers, liabilities, obligations, restrictions, remedies and procedures concerned are to be -

(a) recognised and available in domestic law, and

(b) enforced, allowed and followed accordingly.

(3) Every enactment (including an enactment contained in this Act) is to be read and has effect subject to subsection (2).

4 This was achieved legally by the conduit pipe of s 1B EUWA 2018 ('Saving for EU-derived domestic legislation for implementation period'). 
The striking feature of section $7 \mathrm{~A}$ is how far it draws on the controversial language of section 2(1) European Communities Act 1972 (ECA 1972), ${ }^{5}$ which had been read to give direct effect and supremacy to EU law, and was viewed in UK law as constituting a 'constitutional statute'. We will return to this point later.

The rights of EU citizens in Part Two of the WA apply to the UK, as do the provisions of the Protocol, since section 7A applies to the territory of the UK as a whole. ${ }^{6}$ In addition, section $8 \mathrm{C}$ of the 2018 Act ('Power in connection with Ireland/Northern Ireland Protocol in withdrawal agreement') provides additional powers to implement the Protocol. A minister of the Crown may by regulations make such provision as the minister considers appropriate -

(a) to implement the Protocol on Ireland/Northern Ireland in the withdrawal agreement,

(b) to supplement the effect of section 7A in relation to the Protocol, or

(c) otherwise for the purposes of dealing with matters arising out of, or related to, the Protocol (including matters arising by virtue of section 7A and the Protocol).

\subsection{Enforcement of Rights}

\subsubsection{Introduction}

As we have noted, the text of section 7A EUWA 2018 draws heavily on the original language of section 2(1) ECA 1972, which was understood to give direct effect and supremacy to EU law in the UK. However, section $7 \mathrm{~A}$ is intended to give direct effect and supremacy not to EU law but to

${ }^{5}$ Which reads:

All such rights, powers, liabilities, obligations and restrictions from time to time created or arising by or under the Treaties, and all such remedies and procedures from time to time provided for by or under the Treaties, as in accordance with the Treaties are without further enactment to be given legal effect or used in the United Kingdom shall be recognised and available in law, and be enforced, allowed and followed accordingly; and the expression 'enforceable Community right' and similar expressions shall be read as referring to one to which this subsection applies.

${ }^{6}$ S 24(1) EUWA 2018: 'Subject to subsections (2) and (3), this Act extends to England and Wales, Scotland and Northern Ireland.' This means that the enforcement provisions in Part Six of the WA also apply to breaches of the WA in Northern Ireland as in the rest of the UK. 
the WA, thereby expressly implementing the commitments in Article 4(1) and (2) WA, which provides:

1. The provisions of this Agreement and the provisions of Union law made applicable by this Agreement shall produce in respect of and in the United Kingdom the same legal effects as those which they produce within the Union and its Member States. Accordingly, legal or natural persons shall in particular be able to rely directly on the provisions contained or referred to in this Agreement which meet the conditions for direct effect under Union law.

2. The United Kingdom shall ensure compliance with paragraph 1, including as regards the required powers of its judicial and administrative authorities to disapply inconsistent or incompatible domestic provisions, through domestic primary legislation.

The reference to 'direct effect' in Article 4(1) and 'supremacy' in Article $4(2)$ is a first for an EU Treaty. For good measure, Article $4(3)^{7}$ makes clear that these concepts should be given an EU meaning: 'The provisions of this Agreement referring to Union law or to concepts or provisions thereof shall be interpreted and applied in accordance with the methods and general principles of Union law.'

The acceptance of the supremacy and the direct effect of the WA, via section $7 \mathrm{~A}$, might be thought to be somewhat ironic given the UK's express rejection of the supremacy of EU law by section 1 EUWA 2018 (which turns off section 2(1) ECA 1972), and is reiterated in section 5(1) EUWA 2018.

\subsubsection{Individual Enforcement}

The effect of section 7A EUWA 2018, combined with Article 4(1) WA, is that provisions of the WA can be enforced in UK law by 'individuals', which is EU-speak for natural and legal persons. So, an EU producer who cannot sell its goods in Northern Ireland could challenge a decision by the Northern Ireland authorities in a Northern Ireland court, relying on the principle of direct effect and the supremacy of the WA, and a reference under Article 267 of the Treaty on the Functioning of the European Union (TFEU) can be made by that court to the Court of Justice of the European Union (CJEU) if necessary. ${ }^{8}$

\footnotetext{
7 This is discussed further in Chapter 12.

${ }^{8}$ Under Art 267 (Protocol Art 12(4)).
} 
Similarly, a GB business which cannot sell a good into Northern Ireland because, it argues, a Northern Ireland authority has misapplied one of the many single market regulations that continue to apply in Northern Ireland by virtue of Protocol Annex 2 could bring a claim. Alternatively, a GB (or an EU) business prosecuted for non-compliance with Northern Ireland primary or secondary legislation could raise the incompatibility of that legislation with one of the provisions listed in Annex 2. Any such claim may also raise the incompatibility of the Northern Ireland legislation with Articles 5 and 7 to 10 of the Protocol.

Many of the provisions in the EU regulations and the directives in Annex 2 fulfil the conditions for direct effect (clear, precise and unconditional), and therefore come within Article 4 of the WA, read together with section 7A and section 8C EUWA 2018. They will also have supremacy over conflicting UK law.

\subsubsection{Responsibility of the UK Government}

Protocol Article 12(1) ('Implementation, application, supervision and enforcement') provides that the UK government is responsible for 'implementing and applying the provisions of Union law made applicable by this Protocol to and in the United Kingdom in respect of Northern Ireland'. This means that any breach of the Protocol is the responsibility of the UK government, with the result that the Commission may bring enforcement proceedings against the UK government under Article 258 TFEU in respect of aspects of the Protocol. ${ }^{9}$ As Protocol Article 12(4) provides:

As regards the second subparagraph of paragraph 2 of this Article, Article 5 and Articles 7 to 10, the institutions, bodies, offices, and agencies of the Union shall in relation to the United Kingdom and natural and legal persons residing or established in the territory of the United Kingdom have the powers conferred upon them by Union law. In particular, the Court of Justice of the European Union shall have the jurisdiction provided for in the Treaties in this respect. The second and third paragraphs of Article 267 TFEU shall apply to and in the United Kingdom in this respect.

If the UK does not comply, then further enforcement proceedings may be brought against the UK. Since Protocol Article 12(5) provides that 'Acts of

\footnotetext{
9 https://ec.europa.eu/info/sites/default/files/file_import/Commission_report_2015_infograph _en_0.pdf.
} 
the institutions, bodies, offices, and agencies of the Union adopted in accordance with paragraph 4 shall produce in respect of and in the United Kingdom the same legal effects as those which they produce within the Union and its Member States', the CJEU may also, on the basis of a proposal from the Commission, impose a lump sum or daily penalty payment, or both, on the UK. ${ }^{10}$

In addition to the normal EU system of remedies, Protocol Article 13(1), sub-paragraph 3, makes clear that Part Six of the WA, the Institutional and Final provisions, which include the bespoke dispute resolution mechanism (DRM), also applies. The DRM involves, in essence, a political consultation which - if unsuccessful - is followed by binding arbitration (with the possibility of a reference to the CJEU on matters concerning EU law). ${ }^{11}$ The arbitration panel may ultimately impose financial sanctions. In case of non-payment or persisting noncompliance by one party, the other party may suspend its obligations under the WA (with the exception of the citizens' rights part of the WA) or from the TCA, such as by imposing tariffs on the imports of goods.

\subsubsection{A Case Study}

A dispute that arose soon after the WA and the Protocol took final effect illustrates the practical operation of these provisions, and how they may operate in tandem. As a result of the UK's unilateral decision to extend grace periods under the Protocol in March 2021, the EU deployed a two-pronged approach to enforcement against the UK. VicePresident Maroš Šefčovič sent a political letter to Lord Frost, ${ }^{12}$ the UK's co-chair of the Joint Committee (JC), calling on the UK government to rectify and refrain from putting into practice the statements and guidance published in early March 2021. In its letter, the Commission said:

The Protocol on Ireland and Northern Ireland is the only way to protect the Good Friday (Belfast) Agreement and to preserve peace and stability, while avoiding a hard border on the island of Ireland and maintaining the integrity of the EU single market. The EU and the UK agreed the Protocol together. We are also bound to implement it together. Unilateral decisions and international law violations by the UK defeat its very purpose and undermine trust between us. The UK must properly implement it if we are to achieve our

10 Art 260(2) TFEU applies.

11 See further Chapter 5 on the dispute settlement procedures.

12 https://ec.europa.eu/info/sites/default/files/lettre_to_lord_frost_1532021_en.pdf. 
objectives. That is why we are launching legal action today. I do hope that through the collaborative, pragmatic and constructive spirit that has prevailed in our work so far on implementing the Withdrawal Agreement, we can solve these issues in the Joint Committee without recourse to further legal means.

The letter noted that these unilateral measures are 'a violation of the duty of good faith under Article 5 of the Withdrawal Agreement'. The letter also called on the UK to enter into bilateral consultations in the JC in good faith, with the aim of reaching a mutually agreed solution by the end of March. The reference to the JC concerned consultations prior to the formal commencement of the DRM in Part Six of the WA.

In addition, the Commission sent the UK a Letter of Formal Notice for breaches of substantive provisions of EU law concerning the movement of goods and pet travel made applicable by virtue of the Protocol on Ireland and Northern Ireland. The Commission noted: 'This marks the beginning of a formal infringement process, as set out in Article 12(4) of the Protocol, in conjunction with Article 258 of the Treaty on the Functioning of the European Union', relying on the Commission's supervisory and enforcement powers under the EU Treaties in relation to specific provisions of the Protocol, including Article 5. The letter requested the UK to carry out swift remedial actions to restore compliance with the terms of the Protocol.

The Commission, therefore, triggered two sets of proceedings against the UK, one for breach of Article $5 \mathrm{WA}$ using the bespoke DRM, the second for breach of Protocol Article 5 using the standard Article 258 TFEU enforcement mechanism. In respect of the Article 258 TFEU enforcement proceedings, the UK had a month to submit its observations. Reportedly, it did so with a robust response. In respect of the DRM, the Commission said that 'if the UK fails to enter into consultations in the Joint Committee in good faith, with the aim of reaching a mutually agreed solution by the end of this month, the EU may provide written notice to commence consultations under Article 169 WA, as a first step in the Dispute Settlement Mechanism process set out in Title III of Part Six of the Withdrawal Agreement'. At the end of July 2021, the Commission decided to suspend these proceedings in order to provide the necessary space to reflect ... and find durable solutions to the implementation of the protocol'. ${ }^{13}$

${ }^{13}$ See further 'Update: Developments from July 2021 to September 2021' at the front of this book. 


\subsection{Citizens' Rights}

\subsubsection{The Rules}

In addition to the Protocol, the WA also addresses important issues in respect of citizens' rights in Part Two. These obligations are implemented in the UK by Part Three of the EUWAA 2020. ${ }^{14}$ The 2020 Act provides continued residency rights to all EU citizens and their non-EU family members (NEFM) who exercised their right to reside lawfully in the UK before the end of the transition/implementation period (31 December 2020). It also gives the same rights to Norwegian, Icelandic and Liechtenstein nationals under the European Economic Area-European Free Trade Association (EEA-EFTA) separation agreement, and Swiss nationals under the Swiss citizens' rights agreement. For simplicity, we shall refer to EU citizens throughout, but note that these other groups are also covered. The 2020 Act also protects the existing rights to equal treatment and non-discrimination for EU citizens and their NEFM in the UK.

Children are protected under the WA when they are born to, or legally adopted by, those falling under the WA. This protection may last a lifetime. The deadline for applying is 30 June 2021, but there is the possibility of applying after that date if the individual has 'reasonable grounds'. The Guidance released by the Home Office on what constitutes 'reasonable grounds' says that children are eligible to make an application to the scheme up until they reach the age of eighteen (more on this later).

The WA provides that those who have resided legally in the host state in accordance with Union law for a continuous period of five years have the right to permanent residency and those who have resided in the host state for less than five years have the right to acquire permanent residency once they have completed the required five-year period of residence. ${ }^{15}$

In the UK, EU nationals and their NEFM are granted either settled status (five years or more of residency) or pre-settled status (less than five years' residency). ${ }^{16}$ In the UK, prospective EU settled status applicants need prove only that they have been continuously resident in the UK, rather than that they have been continuously resident and exercising their EU Treaty rights - such as being in work, education, selfemployment or self-sufficiency - as they would if they were applying

${ }^{14}$ EUWAA ss $7-17$ and Sch 2.

15 WA Arts 15-16.

${ }^{16}$ For full details on the EUSS, see Barnard et al, EU Settled Status, Report for UK in a Changing Europe, https://ukandeu.ac.uk/research-papers/the-eu-settlement-scheme/, on which this section draws. 
for benefits. The WA says that the right to permanent residency can be lost only through an absence from the host state for a period exceeding five consecutive years. Those with pre-settled status who need to reapply for settled status will need to evidence their 'continuous' residency in the UK; this means that they must not be absent from the UK for more than six of twelve rolling months.

The WA also sets out some procedural and administrative guidance/ rules regarding issuing residence documents. ${ }^{17}$ It says that the deadline for submitting an application should not be less than six months from the end of the transition period - the UK has implemented this exactly with a 30 June 2021 deadline. The WA says that the administrative procedures for applying must be smooth, transparent and simple, without any unnecessary administrative burdens, and that the application forms must be short, simple and user-friendly. Further, the residence document issued must be free of charge or otherwise not cost more than nationals are charged for similar applications. ${ }^{18}$

The rights of workers and self-employed persons are outlined under the $\mathrm{WA}^{19}$ and these remain broadly the same rights as this group held pre-UK exit from the EU under Union law, including equal treatment protection. The WA also covers the rights of frontier workers - these are people who have their residence in one member state but regularly work in another. It also outlines the continuation of the recognition of professional qualifications cross-borders before the end of the transition period. ${ }^{20}$

Article $30 \mathrm{WA}$ states that EU regulations around social security coordination continue to apply to those who fall within the scope of the WA. As we have seen, in the UK, while settled status confers an automatic 'right to reside' for the purpose of welfare benefits, those with pre-settled status must also satisfy additional requirements - such as being in work in order to be able to access welfare benefits. This tiered distinction between two groups of residency rights holders (ie, those with settled status and those with pre-settled status) in the UK has recently come under scrutiny and is the subject of an appeal as to the legal status of such a distinction. ${ }^{21}$ The outcome of the case will have a significant impact on

17 WA Art 18.

18 An initial planned $£ 65.00$ fee for application was waived in January 2019 by then prime minister Theresa May.

19 WA Arts 24, 25, 26.

20 WA Art 27.

21 The Fratila Tanase case is at the time of writing before the UK Supreme Court, at www .supremecourt.uk/cases/uksc-2021-0008.html. 
the lives of some 2.3 million EU pre-settled status holders residing in the UK.

To oversee the implementation of Part Two of the WA in the UK, an Independent Monitoring Authority (IMA) has been established. ${ }^{22}$ The WA also establishes a JC of the UK and the EU to oversee application of the WA. The CJEU remains partly competent in respect of EU citizens' rights. This means that the UK courts will continue to pay due regard to decisions of the CJEU as well as being able to refer questions of interpretation to the CJEU, where relevant, until 2028.

\subsubsection{What This Means for EU Citizens with (Pre-)Settled Status}

The effect of obtaining (pre-)settled status means that EU citizens will be able to work in both GB and Northern Ireland. (As EU citizens they will also be able to work in Ireland, relying on their free movement rights under EU law.) Any breach of those rules in GB or in Northern Ireland may be challenged in the courts of Northern Ireland or GB, depending on where the breach occurred, relying on the direct effect of the provisions in Part Two of the Protocol, as outlined in Section 9.3 of this chapter. They may also complain to the IMA. For EU citizens arriving in the UK after 1 January 2021, they must either rely on the mobility provisions in the TCA or come under UK domestic immigration law. ${ }^{23}$ UK citizens will continue to be able to live and work in Northern Ireland, and Irish citizens in the UK, by virtue of the terms of the Common Travel Area (CTA), which predated EU membership. ${ }^{24}$ The rights under the CTA have recently been reaffirmed in a Memorandum of Understanding between the UK and Ireland. ${ }^{25}$

\subsection{Conclusions}

The relationship between the UK and the EU during the first few months after the end of the transition/implementation period was described as 'a bit bumpy'. ${ }^{26}$ The UK's reaction to handling the hypersensitive issue of the

${ }^{22}$ S 15 and Sch 2 of the 2020 Act.

23 www.gov.uk/apply-to-come-to-the-uk.

${ }^{24}$ See further Chapter 14. See also www.gov.uk/government/publications/common-travelarea-guidance/common-travel-area-guidance.

25 https://assets.publishing.service.gov.uk/government/uploads/system/uploads/attach ment_data/file/800280/CTA-MoU-UK.pdf.

26 www.standard.co.uk/news/uk/brussels-mps-government-director-house-of-commonsb935646.html. 
Protocol made matters more difficult. The EU followed up what it saw as the UK's non-compliance, triggering the dispute settlement procedures under the WA, albeit this is currently suspended. Private parties may also enforce their rights, but at the time of writing there was no example of this. Meanwhile, EU citizens with settled status enjoy protection similar to that under EU law and also benefit from a robust enforcement mechanism. 